ABDI: Jurnal Pengabdian dan Pemberdayaan Masyarakat ISSN: 2656-369X (Print), 2684-8570 (Online)

Volume 2 No. 1, Juni 2020

http://abdi.ppj.unp.ac.id/index.php/abdi

Email: abdi@ppi.unp.ac.id

DOI: https://doi.org/10.24036/abdi.v2il.54

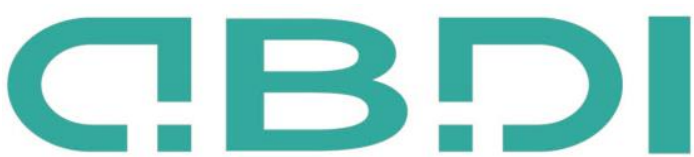

ABDI: JURNAL PENGABDIAN DAN PEMBERDAYAAN MASYARAKAT

\title{
Kerajinan Limbah Cangkang Kerang Sebagai Alternatif Pembuatan Bros Ramah Lingkungan Tambakrejo Semarang
}

\author{
Siti Musapana1, Intan Rizky Amalia ${ }^{2}$ \\ ${ }^{1,2}$ Program Studi Pendidikan Biologi, Universitas PGRI Semarang \\ E-mail: musapana8@gmai1.com, intanamaliara@gmail.com
}

\begin{abstract}
Abstrak
Tambakrejo dikenal dengan daerah pesisir. Hal ini dikarenakan letak kelurahannya dekat dengan pesisir pantai dan mayoritas warganya memang berprofesi sebagai nelayan. Berbagai hasil tangkapan laut yang diperoleh para nelayan Tambakrejo salah satunya adalah kerang. Keberadaan kerang sangat melimpah. Namun kerang yang dihasilkan hanya dimanfaatkan bagian dagingnya saja, sedangkan untuk cangkang kerang hanya menjadi limbah yang tidak dapat diurai oleh tanah. Alternatif yang dilakukan yaitu memanfaatkan limbah cangkang kerang yang diolah menjadi kerajinan tangan bros agar dapat meningkatkan perekonomian warga Tambakrejo yang memiliki nilai estetika dan nilai jual ekonomis. Tujuan penelitian ini adalah untuk mengetahui pemanfaatan limbah cangkang kerang sebagai alternatif kerajinan tangan pembuatan bros ramah lingkungan Tambakrejo, Semarang. Metode penelitian yang digunakan dalam penelitian ini adalah kualitatif dan pengumpulan data dalam penelitian ini menggunakan teknik observasi, wawancara, dan dokumentasi. Untuk menganalisis data hasil penelitian ini diperoleh dari dasar teori yang dalam hal ini digunakan sebagai patokan pengambilan data yang melatar belakangi artkel ini serta observasi secara langsung terhadap objek penelitian, yaitu tentang limbah cangkang kerang yang berada di Tambakrejo Semarang. Berdasarkan penelitian yang telah dilakukan mengenai Kerajinan Tangan Limbah Cangkang Kerang sebagai Alternatif Pembuatan Bros Ramah Lingkungan Tambakrejo Semarang, diketahui bahwa kegiatan ini menjadi solusi dalam meningkatkan potensi yang ada di Tambakrejo, sehingga memiliki berbagai manfaat untuk dibuat kerajinan tangan yang unik dan bisa dimanfaatkan untuk meningkatkan kesejahteraan masyarakat. Selain itu penelitian ini diharapkan mampu mengurangi limbah yang sulit terurai menjadi kerajinan tangan yang memiliki nilai estetika tinggi dan mampu meningkatkan perekonomian warga Tambakrejo Semarang.
\end{abstract}

Kata Kunci: Bros, Inovasi, Kesejahteraan Masyarakat, Limbah Kerang, Lingkungan

\section{Abstract}

Tambakrejo is known as a coastal area. This is because the location of the village is close to the coast most people work as fishermen. Various catches obtained by fishermen, one of which is shellfish. However, the seafood produced is only used as part of the meat, while shells only become waste that difficult to be decomposed by the soil. The alternative is utilizing waste shells that are processed into handicraft brooches to improve the economy of fishers by that have aesthetic value and economical selling value. The purpose of this research is to discover the utilization shell of shellfish waste as an alternative craft to making brooch environmentally friendly in Tambakrejo, Semarang. The research method used in this study is qualitative, and data collection in this study uses observations, interviews, and documentation techniques. To analyze the data of results obtained from the basic theory used as a reference for data collection from the background of this article as well as observations made the object of research directly, about shellfish waste in Tambakrejo Semarang. Based on research that has been done on Shellfish Waste Management as an Alternative to Making Brooch for Environmental Friendly Tambakrejo in Semarang, it is known that activity is a solution in increasing the potential in Tambakrejo so that it has various benefits to be made of unique handicrafts that can be used to increase prosperity and income for Tambakrejo's people. Besides, this research is expected to reduce waste that is difficult to decompose into handicrafts that have high aesthetic value and can improve the economy of Tambakrejo.s people in Semarang.

Keyword: Brooch, Economic Improvement, Environment, Innovation, Shellfish Waste

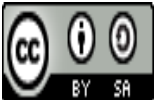

Received: 8 Mei 2020 


\section{Pendahuluan}

Kawasan pesisir berkembang dengan pertumbuhan penduduk yang pesat. Jumlah penduduk sekitar 60\% memadati kota-kota besar seperti Jakarta, Surabaya, Medan, Makasar, dan Semarang (Dahuri, et al, 2001). Salah satu kawasan pesisir di Semarang yaitu Tambakrejo yang terletak di Kelurahan Tanjungmas, Kecamatan Semarang Utara. Lokasinya tidak jauh dari pelabuhan Tanjung emas. Selama ini, Tambakrejo dikenal dengan daerah pesisir. Hal ini dikarenakan sebagain besar warganya memang berprofesi sebagai nelayan dan letak kelurahannya dekat dengan pesisir pantai. Berbagai hasil tangkapan laut di peroleh para nelayan Tambakrejo salah satunya adalah kerang. Namun kerang yang dihasilkan hanya dimanfaatkan bagian dagingnya saja, sedangkan untuk cangkang kerang hanya menjadi limbah yang tidak dapat diurai oleh tanah. Sehingga dapat dijadikan alternatif pembuatan kerajinan tangan bros yang memiliki nilai estetika dan nilai jual yang ekonomis. Saat ini masih banyak nelayan hidup dibawah garis kemiskinan, perlu adanya upaya dengan regulasi mengenai nelayan yang diharapkan bisa meningkatkan kesejahteraan yang lebih baik lagi dari sebelumnya (Muhammad, 2009). Pernyataan ini sesuai dengan kondisi nelayan di pesisir pantai, yang sampai saat ini masih bergelut dengan kemiskinan. Alternatif yang dilakukan yaitu dengan pembuatan bros agar dapat meningkatkan perekonomian nelayan dengan memanfaatkan limbah cangkang kerang yang diolah menjadi kerajinan tangan bros yang memiliki nilai estetika dan nilai jual ekonomis. Pada umumnya proses pembuatan produk dibagi dua yaitu : 1) Proses melalui pemotongan cangkang kerang, 2) Produk hasil sisa proses pemotongan. Dari kedua proses tersebut, akan menghasilkan jenis produk yang berbeda berdasarkan desain berbeda pula. Sehingga dari proses ini pengrajin tetap mengutamakan kreativitas (Hidayat, 2013). Berdasarkan data ekspor hasil perikanan Indonesia pada tahun 2003 dan 2004, untuk komoditas koral dan kulit kerang dihasilkan sekitar 3.208 ton dan 2.752 ton. Limbah padat cangkang kerang ini merupakan sisa industri pengolahan kerang simping, selama ini kerang simping hasil tangkapan nelayan hanya dimanfaatkan daging/otot aduktornya saja sementara cangkangnya dibuang dan menjadi limbah. Besarnya jumlah limbah kulit kerang tersebut secara tidak langsung akan berdampak pada menurunnya kualitas lingkungan dan menurunnya tingkat kesehatan masyarakat setempat. Dari adanya limbah kulit kerang yang melimpah, kualitas lingkungan dan kesehatan masyarakat pesisir menjadi menurun secara tidak langsung. Pengaruh tersebut disebabkan karena sisa dari daging kerang yang tertinggal di kulit kerang mengalami pembusukan sehingga bibit penyakit muncul dari makhluk hidup pengurai (Sawiji \& Perdanawati, 2017).

Berkaitan dengan ketentuan CCRF (Code of Conduct for Responsible Fisheries), maka usaha pengolahan hasil perikanan harus dilakukan lebih optimal dan ramah lingkungan. Menurut (Agustini, et al, 2011), bahwa pemanfaatan limbah kulit kerang dapat dilakukan dengan memanfaatkan nutrisi yang terkandung di dalam kulit kerang sebagai unsur mineral dan senyawa kimia alami untuk berbagai produk, sehingga dapat meningkatkan nilai tambah (added value).

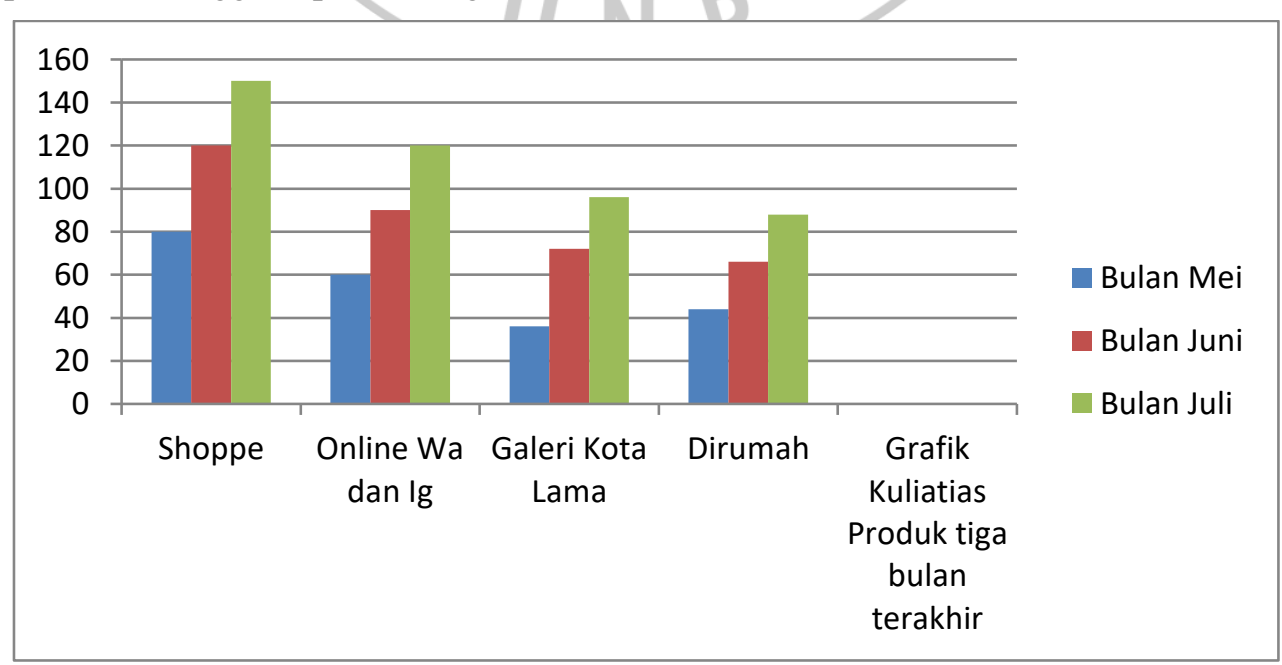

Gambar 1. Tingkat pengeluaran produk bros disetiap penitipan penjualan 
Limbah cangkang kerang yang dihasilkan setiap hari bermacam-macam jenisnya seperti cangkang kerang hijau, kerang gong-gong, kerang simping, dan lainnya yang difokuskan pada kerajinan tangan pembuatan bros. Kerajinan tangan pemanfaatan limbah cangkang kerang menjadi salah satu tolak ukur pada setiap produksi dan tingkat pemesanan pelanggan. Seperti halnya, di salah satu tempat penitipan produk bros contohnya di galeri mendapat perhatian khusus dari pengunjung Asing. Salah satu pendatang Asing yang mengunjungi dari Australia memberikan apresiasi ketertarikan dari bahan yang digunakan seperti limbah yang kemudian diolah menjadi produk yang bermanfaat, estetik dan memiliki nilai jual tinggi. Tujuan penulisan artikel ini adalah untuk mengetahui pemanfaatan limbah cangkang kerang sebagai alternatif kerajinan tangan pembuatan bros ramah lingkungan Tambakrejo, Semarang.

\section{Metode Pelaksanaan}

Penelitian ini dilakukan di Desa Tambakrejo, Semarang Utara. Waktu pelaksanannya pada 5-6 Oktober 2019. Kemudian metode penelitian yang digunakan dalam penelitian ini adalah kualitatif dan pengumpulan data dalam penelitian ini menggunakan teknik observasi, wawancara, dan dokumentasi. Jadwal kegiatan penelitian Kerajinan Tangan Limbah Cangkang Kerang sebagai Alternatif Pembuatan Bros Ramah Lingkungan Tambakrejo Semarang.

\section{Tabel 2. Jadwal Kegiatan Penelitian}

\begin{tabular}{cc}
\hline Hari/Tanggal & Jumlah Warga \\
\hline Sabtu, 5 Oktober 2019 & Survei Lokasi \\
Minggu, 6 Oktober 2019 & Observasi, Wawancara, Dokumentasi \\
\hline
\end{tabular}

Tabel tersebut menunjukkan jadwal yang dilakukan secara langsung untuk melihat kondisi tempat pembuatan bros dengan melakukan wawancara untuk mencari informasi pemanfaatan limbah cangkang kerang yang diolah menjadi bros. Observasi dilakukan di daerah pesisir Tambakrejo Semarang, kemudian mengambil dokumentasi yang diambil dari hasil pembuatan kerajinan tangan dari limbah cangkang kerang yang dibuat bros dengan melakukan pengambilan gambar berupa foto. Teknik wawancara yang digunakan dalam penelitian ini secara face to face dan tertulis yaitu dengan memberikan beberapa pertanyaan yang sudah dipersiapkan yang ditujukan kepada Ibu Nana selaku pemilik usaha kerajinan tangan dari limbah cangkang kerang. Data - data dari hasil penelitian dikumpulkan dan dianalisis dengan metode kualitatif dan bersifat deskriptif. Hasil analisis data ini diperoleh dari dasar teori yang digunakan sebagai patokan pengambilan data yang menjadi latar belakang adanya karya ilmiah ini, serta observasi yang dilakukan secara langsung terhadap objek penelitian, yaitu limbah cangkang kerang yang berada di Tambakrejo Semarang.

Wawancara dilakukan secara langsung dengan iIbu Nana yang merupakan salah satu warga di daerah Tambakrejo bahwa beliau mempunyai ide dengan menciptakan inovasi untuk membuat kerajinan tangan dari limbah cangkang kerang yang mempunyai potensi dalam pengolahan limbah cangkang kerang. Alternatif pembuatan bros kerajinan tangan dari limbah cangkang kerang menghasilkan produk yang unik berupa bros yang menggunakan limbah cangkang kerang.

\section{Hasil dan Pembahasan}

Setelah dilakukan kegiatan penelitian mengenai Kerajinan Tangan Limbah Cangkang Kerang sebagai Alternatif Pembuatan Bros Ramah Lingkungan Tambakrejo Semarang, diketahui bahwa kegiatan ini memiliki tujuan untuk meningkatkan potensi yang ada di Tambakrejo, yang memiliki berbagai manfaat untuk dibuat kerajinan tangan yang unik dan bisa dimanfaatkan untuk meningkatkan taraf hidup masyarakat serta menambah penghasilannya yang ada di masyarakat.(Afrian et al., 2019) Meskipun pada data menyebutkan bahwa produktivitas nelayan masih rendah dan tidak mampu untuk 
mengalihfungsikan hasil tangkapan, tidak menutup kemungkinan dengan adanya warga yang peduli terhadap permasalahan ini dengan usahanya memberdayakan masyarakat pesisir untuk lebih inovatif (Mariana, 2016)

Adapun hal penting dalam kegiatan ini untuk menginformasikan kepada warga-warga sekitar bahwa daerah Tambakrejo memiliki potensi yang sudah dilakukan Ibu Nana sebagai narasumber mengenai idenya dalam mengolah limbah cangkang kerang yang melimpah dan dibuat menjadi kerajinan tangan seperti bros, sehingga dapat membuka lapangan pekerjaan bagi warga untuk bekerja di bidang pembuatan kerajinan tangan. Limbah cangkang kerang yang digunakan didapatkan dari nelayan-nelayan yang hanya mengambil bagian isi kerangnya saja ataupun mencari sisa-sisa limbah yang melimpah disekitar pesisir.

Dari hasil wawancara dengan Ibu Nana mengenai pembukaan lowongan pekerjaan untuk membuat kerajinan tangan bros, dari pihak yang membantu Ibu Nana meminta bahwa gaji yang diberikan harus sama dengan gaji yang ada di pabrik-pabrik yang dekat dengan Tambakrejo Semarang yaitu sekitar 60 ribu/hari. Ibu Nana mencari tenaga kerja untuk membantunya dalam pembuatan bros. Tetapi setiap ada warga yang membatu dalam pembuatan kerajinan tangan bros warga merasa bosan dan jenuh dalam membuat bros karena setiap orang belum tentu ahli dalam melakukan kerajinan tangan pembuatan bros. Pada akhirnya Ibu Nana melakukan pekerjaannya dengan melibatkan anak-anaknya dengan tenaga yang sangat terbatas. Berdasarkan hasil penilaian disajikan data berupa tabel 3 .

\section{Tabel 3. Penyajian Data berupa Harga Bros}

\begin{tabular}{lcll}
\hline \multicolumn{1}{c}{ Jenis Bros } & Harga & \multicolumn{1}{c}{ Keterangan } \\
\hline Biasa (1-2 bahan non kerang) & 3rb-15rb & $\begin{array}{l}\text { Bahan yang dipakai hanya kerang dan 1 } \\
\text { bahan non kerang } \\
\text { Bahan yang dipakai dengan } \\
\text { menambahkan mutiara tawang }\end{array}$ \\
Sedang (2-3 bahan non kerang) & 25rb 50rb & $\begin{array}{l}\text { Bahan dengan menambahkan mutiara } \\
\text { tawang dan rantai berwarna emas }\end{array}$ \\
\hline Rumit (lebih dari 3 bahan non kerang) & 75rb-159rb &
\end{tabular}

Dalam pengerjaannya, setiap 2 minggunya dapat membuat sebanyak 200 pcs bros dengan penghasilan mencapai 2,5 juta. Untuk dapat memasarkan produknya, Ibu Nana menitipkan produknya ke penjual aksesoris di kota lama dengan memberikan tenggang waktu selama 1 bulan, Ibu Nana juga menitipkan produknya melalui anaknya untuk dapat menawarkan di sekolahnya, kemudian Ibu Nana menawarkan produk dengan memperluas jejaring (relasi) di acara pameran (galeri).

\subsection{Ramah Lingkungan}

Lingkungan di daerah Tambakrejo semakin terlihat bersih, dikarenakan adanya timbul rasa peduli yang dilakukan dari Ibu.. terhadap lingkungan di daerah tersebut dengan memanfaatkan limbah cangkang kerang yang membuat perekonomian keluarganya meningkat. Ibu Nana menyampaikan bahwa warga meminta untuk bayaran ke Ibu Nana dengan harian 100 ribu, tetapi bayaran yang diminta oleh warga harus sama dengan gaji pabrik. Warga yang membantu Ibu Nana merasa jenuh entuk membuat kerajinan tangan bros. Maka warga tertarik gaji yang lebih besar di pabrik dibandingkan kerja di tempat Ibu Nana yang hanya membuat kerajinan tangan bros.

\subsection{Inovasi}

Dengan melihat keadaan masyarakat pesisir yang sebagian besar merupakan nelayan dimana setiap harinya menghasilkan kerang dengan jumlah melimpah, namun yang diambil hanya bagian daging kerangnya saja. Sedangkan cangkang kerangnya tidak dimanfaatkan dengan baik. Hal itu membuat Ibu Nana memiliki ide memanfaatkan bagian cangkang kerang untuk dibuat bros yang selama ini hanya menjadi limbah, selain itu dengan adanya bros dapat dijadikan kerajinan khas Tambakrejo supaya lebih dikenal oleh masyarakat luas. 


\subsection{Nilai Estetik}

Limbah cangkang memiliki potensi dan peluang yang sangat besar untuk meningkatkan perekonomian masyarakat pesisir. Pembuatan kerajinan bros mampu memperdayakan limbah hasil laut. Pendayagunaan modal sosial tersebut dapat menjadi media pemberdayaan masyarakat dan penciptaan lapangan kerja (Erwin et al, 2013). Bros dari limbah cangkang kerang digunakan untuk mempercantik busana penampilan khususunya bagi para wanita. Membuat penampilan seseorang terlihat berbeda hanya dengan menyematkan bros pada baju atau jilbab. Dengan melihat bentuk dan motif dari cangkang yang unik, semakin menambah nilai estetik. Produk bros ini mampu meningkatkan daya tarik tersendiri bagi masyarakat dengan adanya pemanfaatan limbah cangkang kerang yang semula tidak berguna menjadi produk yang memiliki nilai estetika dan nilai jual tinggi (Widyastuti, 2019).

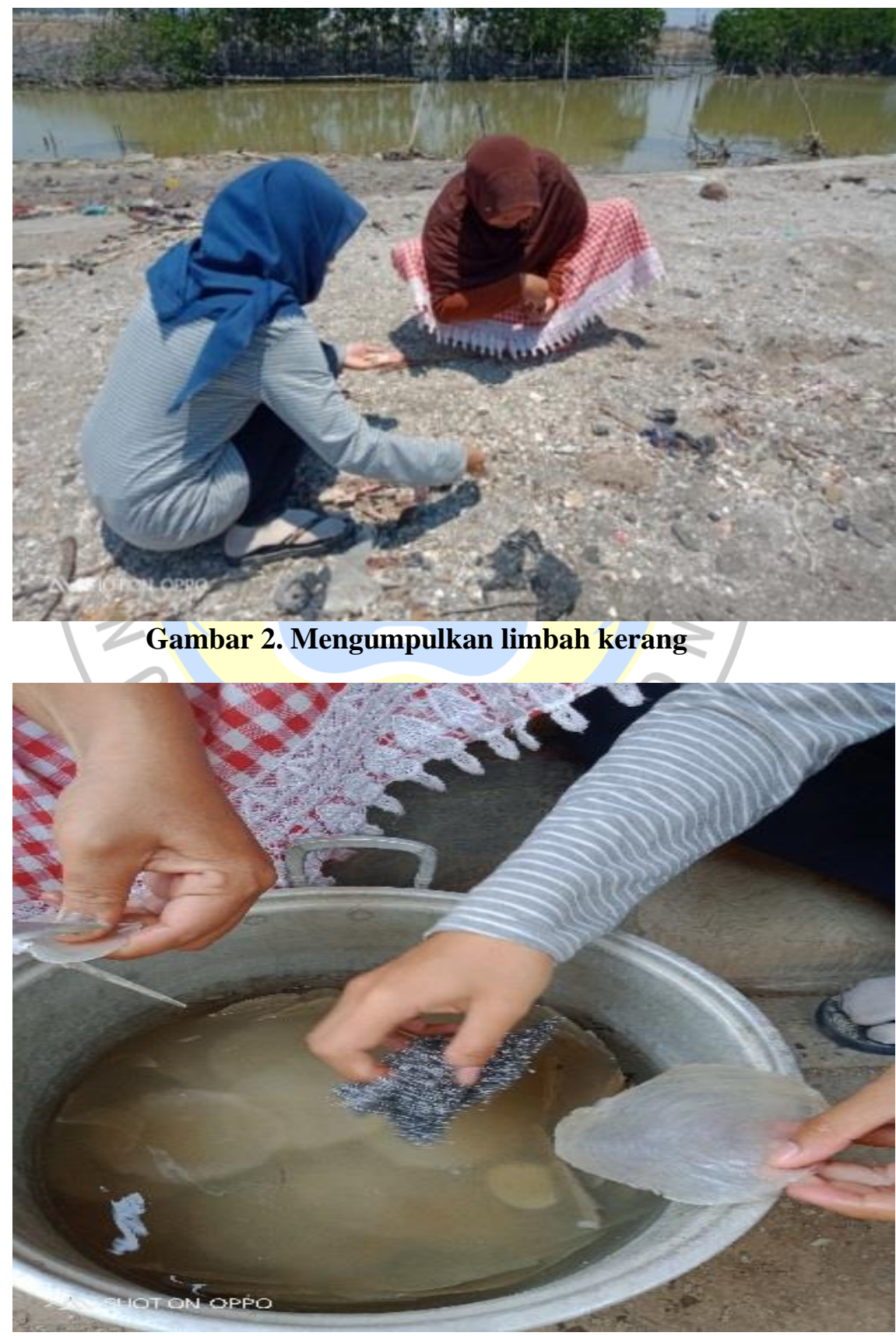

Gambar 3. Membersihkan limbah kerang 
Siti Masupana, Intan Rizky Amalia Kerajinan Limbah Cangkang Kerang Sebagai Alternatif Pembuatan Bros Ramah Lingkungan Tambakrejo Semarang

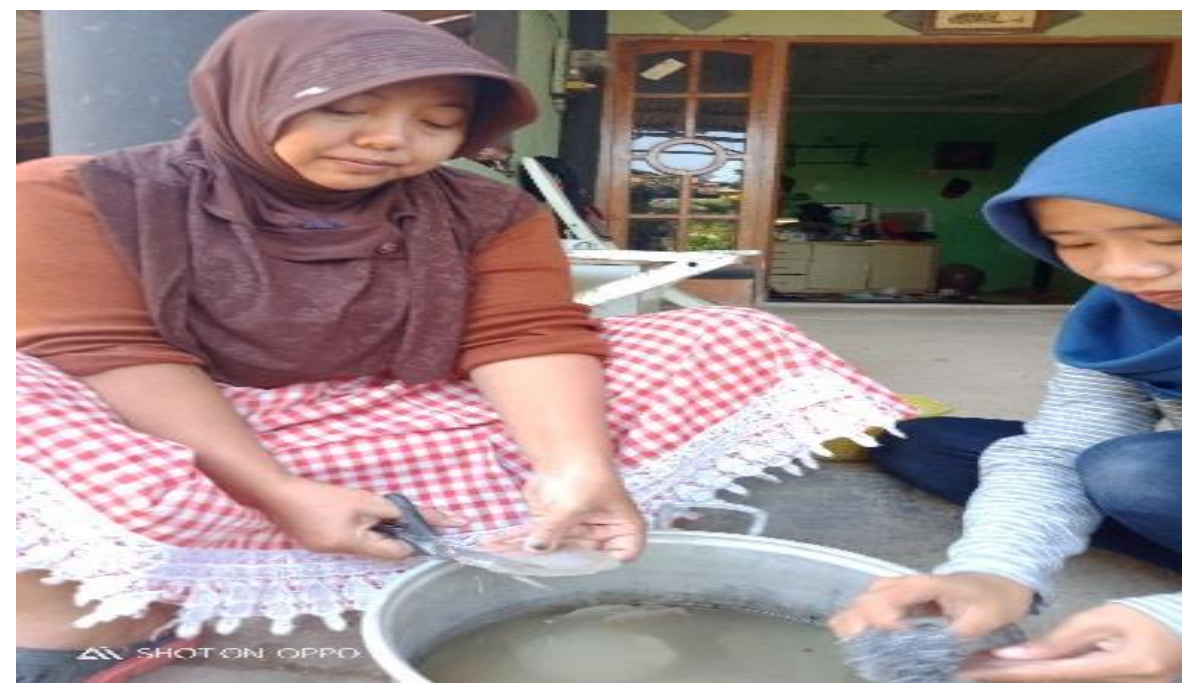

Gambar 4. Memotong kerang dengan menyesuaikan bentuk

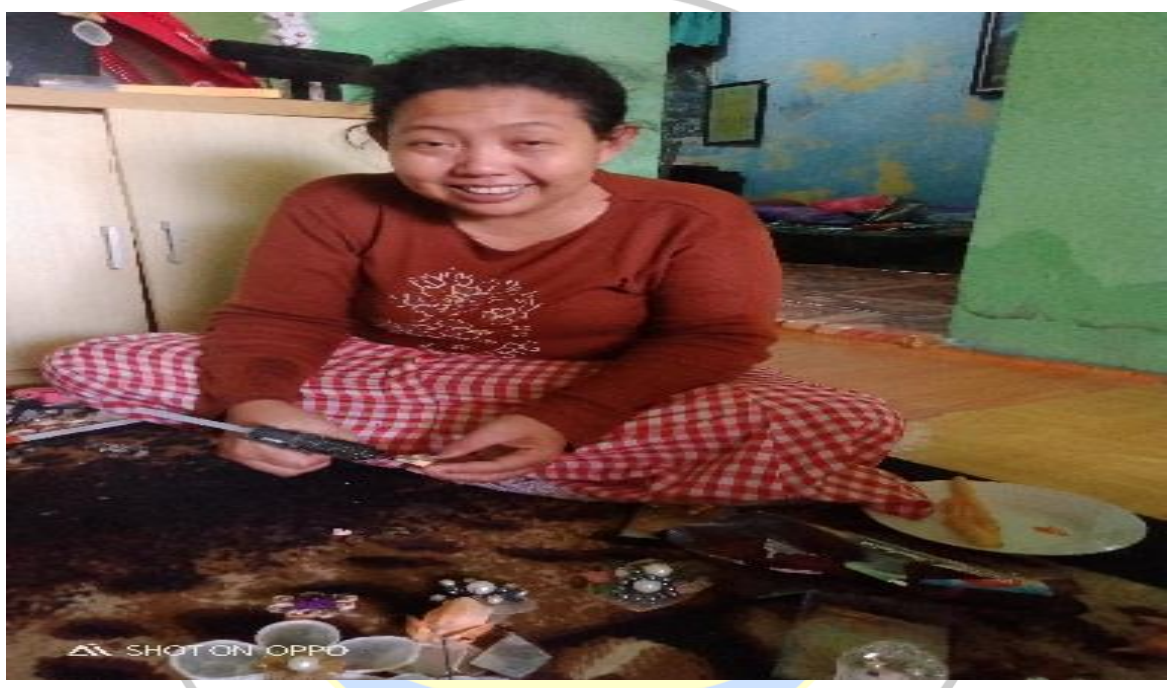

Gambar 5. Menempelkan hiasan bahan non kerang pada limbah kerang

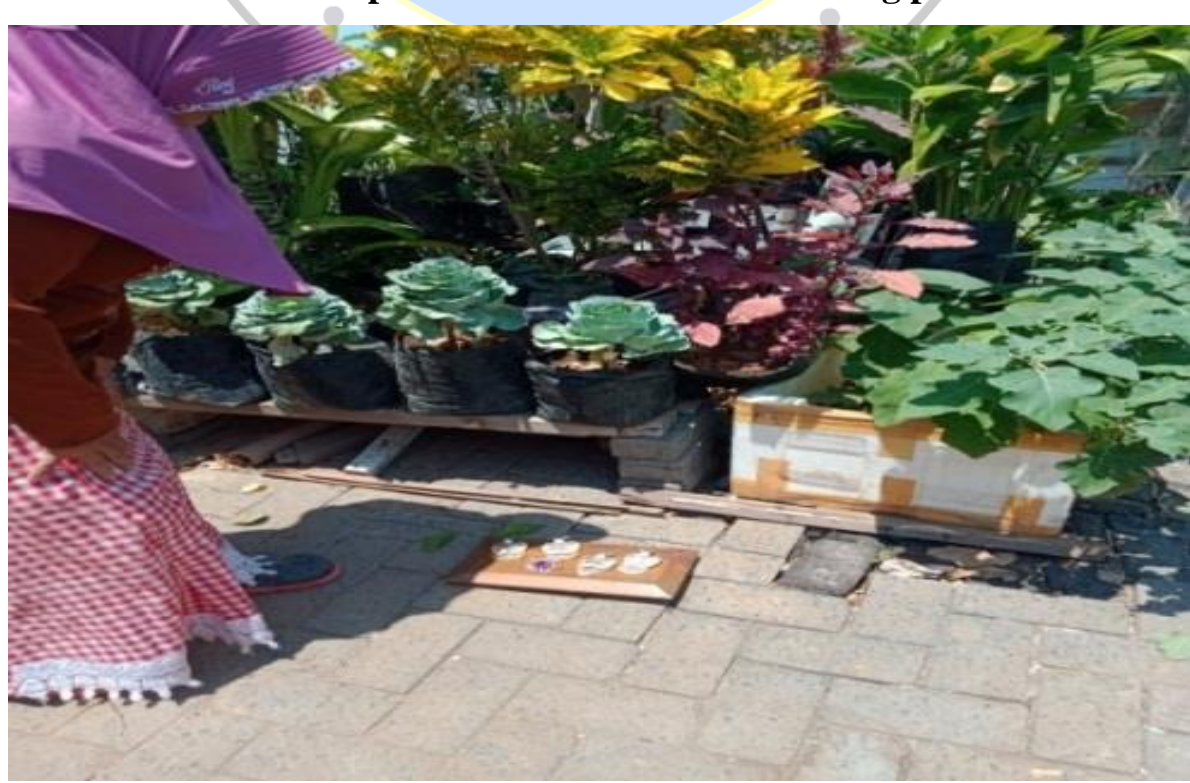

\section{Gambar 6. Mengeringkan produk}

ABDI: Jurnal Pengabdian dan Pemberdayaan Masyarakat Vol. 2 No. 1 
Siti Masupana, Intan Rizky Amalia Kerajinan Limbah Cangkang Kerang Sebagai Alternatif Pembuatan Bros Ramah Lingkungan Tambakrejo Semarang

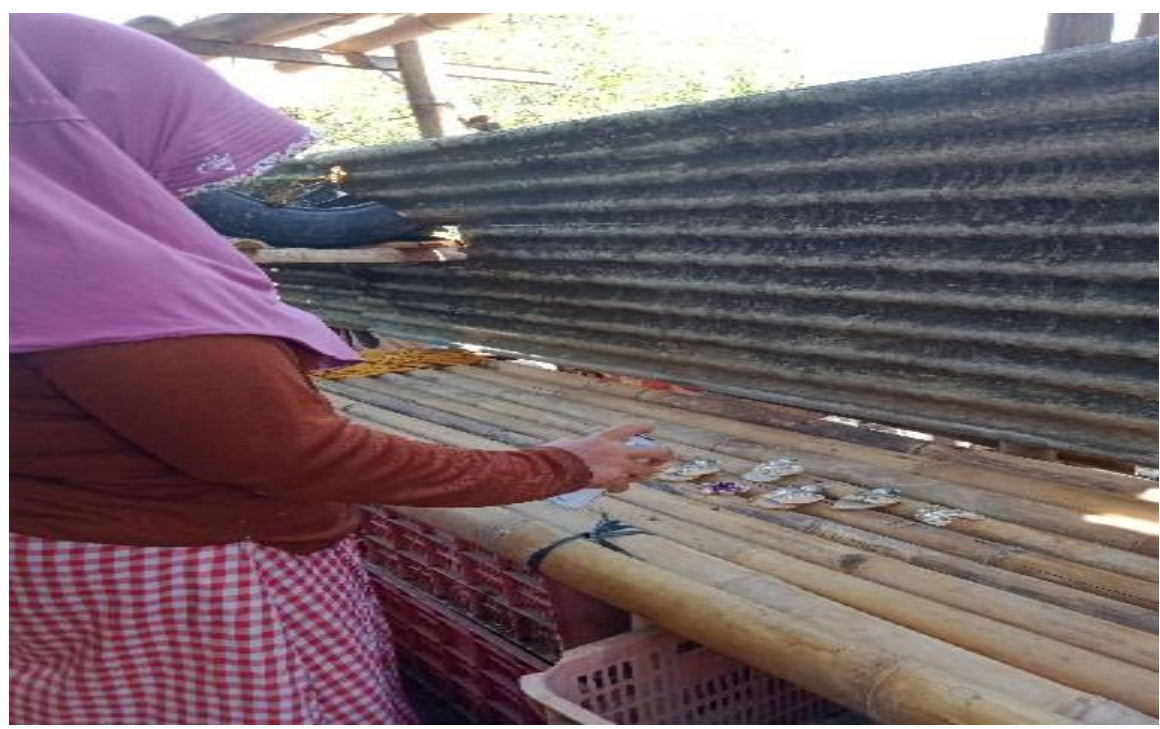

Gambar 7. Mengkilapkan/vernis produk

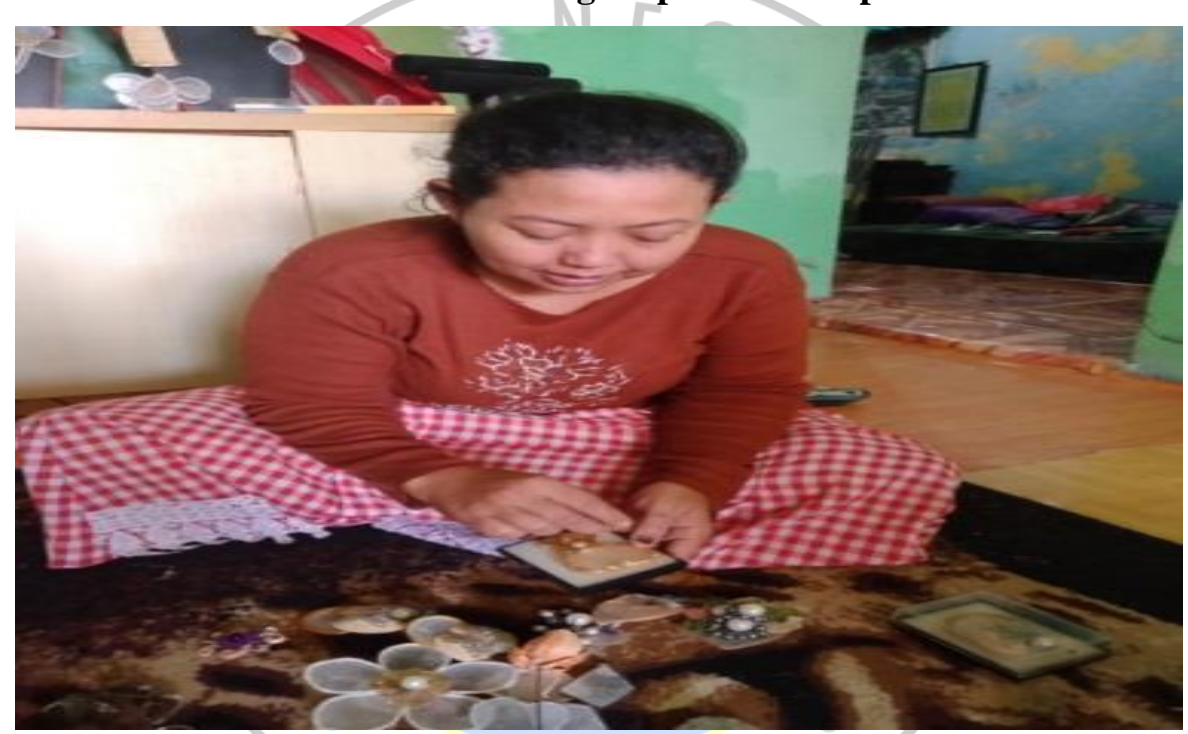

Gambar 8. Mengemas produk

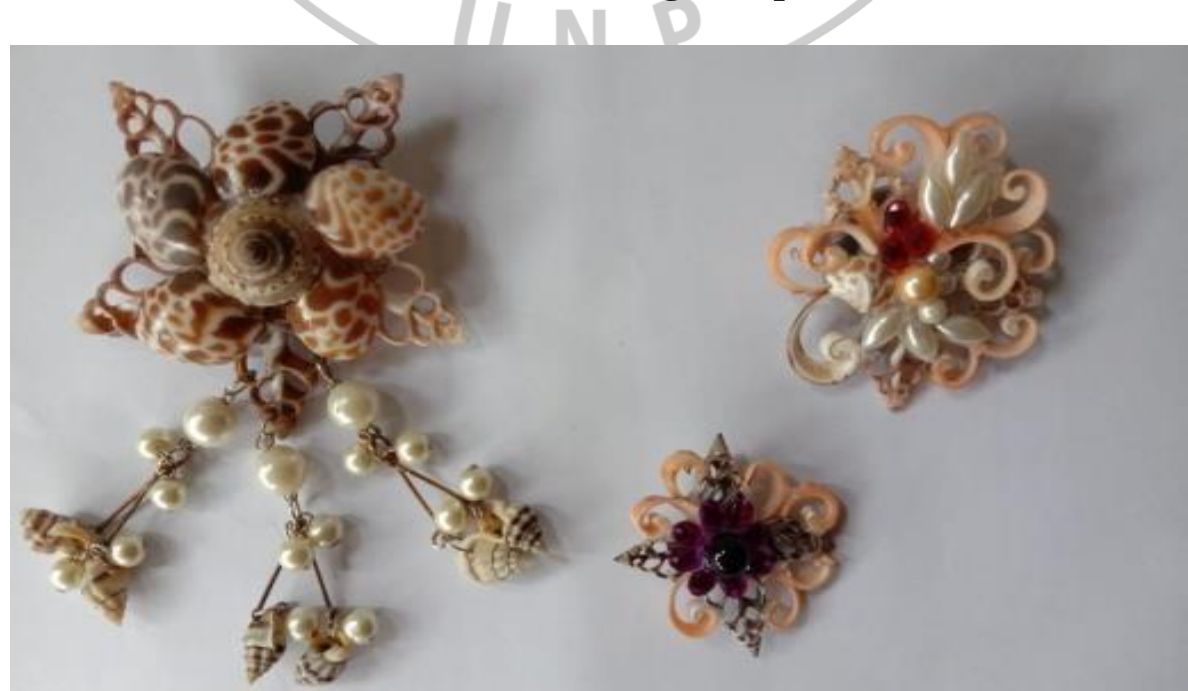

Gambar 9. Hasil Produk

ABDI: Jurnal Pengabdian dan Pemberdayaan Masyarakat Vol. 2 No. 1 E-ISSN: 2684-8570| ABDI 2020 Copyright $\odot$ 2020, By Author 


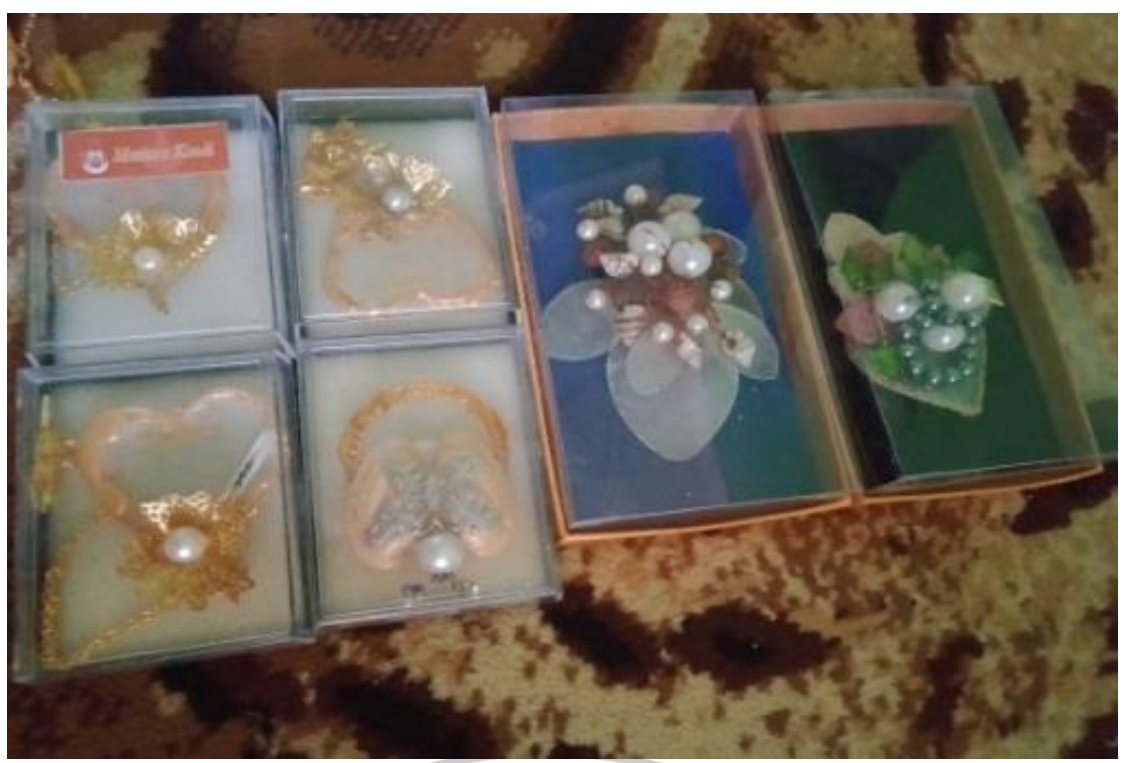

Gambar 10. Hasil produk yang sudah dikemas

\section{Kesimpulan}

Dari penelitian yang telah dilakukan Ibu Nana mengenai kerajinan tangan limbah cangkang kerang sebagai alternatif pembuatan ros ramah lingkungan Tambakrejo Semarang diharapkan warga sekitar bisa mengolah limbah yang perpotensi nilai jual yang sangat tinggi. Warga tidak usah bekerja di pabrik tetapi bisa membuka lapangan pekerjaan sendiri. Mereka diberdayakan untuk meningkatkan keterampilan (skill) dengan adanya diberikannya pelatihan yang sebelumnya belum terpikirkan dibenak mereka mengenai pemanfaatnn limbah cangkang kerang menjadi bros.

Saran yang penulis berikan semoga dapat memberikan manfaat bagi seluruh pihak yang terkait dimana diharapkan penelitian ini dapat dikembangkan dalam penelitian selanjutnya sehingga penelitian mendapatkan data bahwa warna mempunyai berbagai inovasi yang baru. Ucapan terima kasih penulis sampaikan kepada pihak tambak rejosari Semarang yang telah memberikan izin dan dukungan untuk menjadi jembatan bagi terselenggaranya mengenai aksesoris bros Penulis juga tak lupa ucapkan terima kasih kepada Penyelenggara atas kesempatan dalam melaksanakan kegiatan pelatihan untuk mendukung artikel yang penulis buat. 


\section{Daftar Pustaka}

Afrian, R., Islami, Z. R., Suciani, A., Rahmadi, M. T., Geografi, P. P., Samudra, U., \& Barat, L. (2019). Produk Lampu Hias: Cangkang Padat Cangkang Tiram yang Dihasilkan. Global Science Society: Jurnal Ilmiah Pengabdian Kepada Masyarakat, 1(1), 50-55.

Agustini, W, Tri, Fahmi, Suhaedi, A, Widowati Ita, \& Sarwono, A. (2011). Pemanfaatan Limbah Cangkang Kerang Simping (Amusium pleuronectes) dalam Pembuatan Cookies Kaya Kalsium. Jurnal Pengolahan Hasil Perikanan Indonesia, 14 (1), 8-13.

Dahuri, R., Rais J., Ginting S.P., Sitepu, M. (2001). Pengelolaan Sumberdaya Wilayah Pesisir dan Lautan Secara Terpadu. Jakarta: PT. Pradnya Paramita.

Muhammad, F. (2009). Reinventing Local Government: Pengalaman dari Daerah. Jakarta: Gramedia.

Hidayat, A. (2013). Analisis Pengaruh Citra Merek, Kualitas Produk dan Harga Terhadap Kepuasan Pelanggan Serta Dampaknya Terhadap Loyalitas Pelanggan (Studi Kasus pada Member PT Melia Sehat Sejahtera di UIN Syarif Hidayatullah Jakarta). Skripsi. UIN Syarif Hidayatullah Jakarta

Islam M. Z, Lamberg-Allardt, C, Karkkainen M. (2003). Dietary calcium intake in premenopausal Bangladeshi women: do socioeconomic or physiological factors play a role? Journal of Clinical Nutrition, 57, 674-680.

Mariana, K. (2016). Pemberdayaan Masyarakat Pesisir Pantai Melalui Pendekatan Iczm (Integrated Coastal Zone Management). Prosiding Seminar Nasional Multi Disiplin Ilmu \& Call for Papers Unisbank. Unisbank Semarang.

Sawiji, A., \& Perdanawati, R. A. (2017). Pemetaan Pemanfaatan Limbah Kerang dengan Pendekatan Masyarakat Berbasis Aset (Studi Kasus: Desa Nambangan Cumpat, Surabaya). Marine Journal, 3(1), 10-19.

Erwin, T. et al. (2013). Pengaruh modal sosial terhadap perilaku kewirausahaan; Suatu studi pada pelaku usaha mikro kecil menengah di Kecamatan Kabaruan Kabupaten Kepulauan Talaud. Jurnal Acta Diurna, 2(2), 1-10.

Widyastuti, D. A., \& Nurdyansyah, F. (2019). Pemberdayaan Wanita Tani Kabupaten Kudus dalam Pembuatan Saus Cabai (Capsicum anuum). Jurnal Surya Masyarakat, 1(2), 81-84. https://doi.org/10.26714/jsm.1.2.2019.81-85 